\title{
A Acta Cirúrgica Brasileira e o Journal Citation Reports
}

\author{
Lilian N. Caló \\ Coordenadora de Comunicação Científica e Avaliação, BIREME/OPAS/OMS
}

AActa Cirurgica Brasileira (ACB) completa em 2010 vinte e cinco anos de sua fundação e dois anos de indexação na Web of Science e é grande a expectativa de seu possível ingresso no Journal Citation Reports (JCR), que publica os fatores de impacto (FI) dos periódicos.

Mas antes mesmo de ingressar no concorrido JCR, a ACB já possui seu FI calculado pelo professor Rogério Meneghini, Coordenador Científico do Programa SciELO. Com base nas citações recebidas em 2006 e 2007 e no número de trabalhos publicados nestes dois anos, Meneghini prevê um FI de 0,551 para a Acta, "um valor muito significativo para periódicos de países emergentes".

Mas apesar de ser um fato que é valorizado enormemente por muitos editores, a ACB, como me revelou o seu editor, Prof. Saul Goldenberg, não aguardará a divulgação dos contemplados de 2010, que ocorre em junho, com grande expectativa. Este é um sinal de maturidade e a ACB já alcançou esta maturidade. Independente de ingressar ou não no JCR, de ser ranqueado por um indicador de desempenho ou não.

O FI é um índice desenvolvido por uma empresa com interesses comerciais que não mede simplesmente a excelência do conjunto de artigos de um periódico. No numerador está o número de citações que, é influenciado por determinados fatores. Sabe-se, por exemplo, que artigos de revisão captam mais citações que artigos originais. Desta forma, há editores aumentando consideravelmente o número de revisões proporcionalmente em cada número da revista. Outro artefato usado pelos editores é publicar comentários de artigos, que também geram muitas citações. O denominador, por outro lado, inclui apenas trabalhos originais e artigos de revisão.

Apesar da vulnerabilidade deste algoritmo, ele continua sendo amplamente utilizado e celebrado pela comunidade científica. A causa seria a falta de algum outro índice bibliométrico de tão largo espectro e internacionalmente aceito, que permita normalizar a produção científica acadêmica para permitir avaliações e comparações de mérito e desempenho da produção científica.

Não causa surpresa o fato que o uso de um indicador torne elegível um ou outro autor pelo fato de que tenha publicado em um periódico de mais alto FI, de que é mais importante saber onde ele publicou do que ler seu trabalho?

No entanto, comparações de desempenho são necessárias e indicadores vão continuar a existir; novos indicadores serão criados e críticas a estes também surgirão.

O que é necessário ter em mente ao editar um periódico científico é realizar um trabalho com seriedade para divulgar a ciência aos pares. O reconhecimento e os indicadores de desempenho certamente virão. 